Canadian

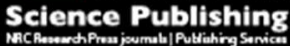

Canadian Journal of Zoology Revue canadienne de zoologie

\title{
Does the number of genital organs matter? Case of the seal tapeworm Diphyllobothrium (syn. Diplogonoporus) tetrapterum (Cestoda: Diphyllobothriidea)
}

\begin{tabular}{|r|l|}
\hline Journal: & Canadian Journal of Zoology \\
\hline Manuscript ID & cjz-2017-0013.R1 \\
\hline Manuscript Type: & Article \\
\hline Complete List of Authors: & $\begin{array}{l}\text { Hernandez-Orts, Jesus; Centro de Investigación Aplicada y Transferencia } \\
\text { Tecnológica en Recursos Marinos Almirante Storni (CIMAS - CCT CONICET) } \\
\text { y Escuela Superior de Ciencias Marinas (ESCiMar), Universidad Nacional del } \\
\text { Comahue, Güemes } \\
\text { Scholz, Tomáš; Institute of Parasitology } \\
\text { Brabec, Jan; Institute of Parasitology, Biology Centre, Czech Academy of } \\
\text { Sciences } \\
\text { Kuzmina, Tetiana; Schmalhausen Institute of Zoology NAS of Ukraine } \\
\text { Kuchta, Roman; Institute of Parasitology, Biology Centre, Czech Academy } \\
\text { of Sciences, Helminthology }\end{array}$ \\
\hline Keyword: & $\begin{array}{l}\text { cestode, duplication of genitalia, plerocercoids, Diphyllobothriidae, } \\
\text { MORPHOLOGY < Discipline, TAXONOMY-SYSTEMATICS < Discipline, } \\
\text { PHYOGENY < Discipline }\end{array}$ \\
\hline \multicolumn{2}{|c}{} \\
\hline
\end{tabular}




\title{
Does the number of genital organs matter? Case of the seal tapeworm Diphyllobothrium
} (syn. Diplogonoporus) tetrapterum (Cestoda: Diphyllobothriidea)

Jesús S. Hernández-Orts, Tomáš Scholz, Jan Brabec, Tetiana Kuzmina, Roman Kuchta

J.S. Hernández-Orts. Centro de Investigación Aplicada y Transferencia Tecnológica en Recursos Marinos Almirante Storni (CIMAS - CCT CONICET) y Escuela Superior de Ciencias Marinas (ESCiMar), Universidad Nacional del Comahue, Güemes 1030, 8520, San Antonio Oeste, Río Negro, Argentina.

T. Scholz, J. Brabec and R. Kuchta. Institute of Parasitology, Biology Centre of the Czech Academy of Sciences, Branišovská 31, 37005 České Budějovice, Czech Republic.

T. Kuzmina. Schmalhausen Institute of Zoology NAS of Ukraine, 15, Bogdana Khmelnytskogo Street, 01030, Kyiv, Ukraine.

Corresponding author: Roman Kuchta (email: krtek@paru.cas.cz)

\begin{abstract}
:
The seal tapeworm Diphyllobothrium tetrapterum (von Siebold, 1848) Baer, 1932 (syn. Diplogonoporus tetrapterus) is exceptional among cestodes because it possesses two types of the strobila, one with a multiple set of genitalia per proglottid and another with a single set of reproductive organs per proglottid. In this study, Diph. tetrapterum is redescribed on the basis of extensive, well-fixed material from the northern fur seal, Callorhinus ursinus (L., 1758), from Alaska. A critical morphological and molecular study of comprehensive material from several hosts throughout the Northern Hemisphere is provided. As a result, Dipl. mutabilis and Dipl. violettae become junior synonyms of Diph. tetrapterum. Our study provides evidence of intraspecific and even individual variability of Diph. tetrapterum in the number of
\end{abstract}


genital complexes, thus making this generic feature questionable for circumscription of diphyllobothriid genera. The seal tapeworm has been found exclusively on the Northern Hemisphere and exhibits a wide (euryxenous) specificity at the level of the definitive host, having been found in a number of seals, the sea otter Enhydra lutris (L., 1758) and exceptionally in other terrestrial mammals. Plerocercoids of Diph. tetrapterum are reported from the second (fish) intermediate host for the first time, in this case the pink salmon Oncorhynchus gorbuscha (Walbaum, 1792) from Alaska.

Key words: cestode, cox1, Diphyllobothriidae, duplication of genitalia, helminths, $l s r$ DNA, morphology, phylogeny, pink salmon Oncorhynchus gorbuscha, plerocercoids, sea otter Enhydra lutris, Pinnipedia

\section{Introduction}

Diphyllobothriidean tapeworms are the most common helminths of marine mammals (Delyamure 1955; Kuchta and Scholz 2017), with most of the species having been described more than 150 years ago. However, our knowledge of their systematics still remains poor (Delyamure et al. 1985; Kamo 1999), which is also true for Diphyllobothrium tetrapterum (von Siebold, 1848) Baer, 1932 (syn. Diplogonoporus tetrapterus; see Waeschenbach et al. 2017). This species was briefly described as Bothriocephalus tetrapterus by von Siebold (1848) from the intestine of an unidentified seal and unknown locality. Thereafter, Krabbe (1865) described three additional species from seals and some terrestrial mammals from Iceland and Greenland, all very similar to the Siebold's species. Two additional, morphologically similar species, Dipl. mutabilis Belopolskaya, 1960 and Dipl. violettae Yurakhno, 1986, were described more recently (Belopolskaya 1960; Yurakhno 1986). 
All these tapeworms are characterized by the multiplication of reproductive organs in proglottids, which are usually doubled (i.e. diplogonadic forms). This morphological character was used by Lönnberg (1892) to characterize his new genus Diplogonoporus Lönnberg, 1892, with the type species Dipl. balaenopterae Lönnberg, 1892 described from whales, but later also reported from man and dogs (Rausch 1964; Scholz and Kuchta 2016). However, the taxonomic utility of this character was doubted by Baer (1932) and Rausch (1964), and the validity of the genus was later questioned by molecular phylogenetic studies (Yamasaki et al. 2012, 2016), which showed its close relationship to Diphyllobothrium stemmacephalum Cobbold, 1858, the type species of the genus Diphyllobothrium Cobbold, 1858. Recently, Waeschenbach et al. (2017) confirmed synonymization of Diplogonoporus with Diphyllobothrium.

The aim of the present study is to critically review the diplogonadic tapeworms from pinnipeds and the sea otter based on the evaluation of new and museum material including type material of several diplogonadic species. In addition, the taxonomic importance of the number of genital complexes in diphyllobothriid tapeworms is discussed and the first record of plerocercoids of Diph. tetrapterum in fish intermediate host is provided.

\section{Materials and methods}

\section{Specimen collection}

A total of 756 northern fur seals Callorhinus ursinus from St. Paul Island, Alaska, USA $\left(57^{\circ} 09^{\prime} \mathrm{N} ; 170^{\circ} 13^{\prime} \mathrm{W}\right)$ were examined during the summers of 2011-2014 (see Kuzmina et al. 2015 for details). A total of 1,559 specimens of Diph. tetrapterum were found in the intestines. Cestodes were washed in saline and fixed in hot $\left(>90^{\circ} \mathrm{C}\right)$ tap water and stored in $70 \%$ ethanol. Additionally, one incomplete specimen of Diplogonoporus sp. was obtained 
from carcass of a sea otter Enhydra lutris nereis (Merriam) from Monterey County, California, USA (Young et al. 2017).

Two live plerocercoids of Diphyllobothrium sp. were found encysted in the stomach wall and liver in two out of 56 pink salmons Oncorhynchus gorbuscha from the Resurrection Creek, Hope, Kenai Peninsula $\left(60^{\circ} 55^{\prime} 10^{\prime \prime N}\right.$; $149^{\circ} 38^{\prime} 31^{\prime \prime}$ ) and the Susitna River, Willow $\left(61^{\circ} 46^{\prime} 10^{\prime \prime} \mathrm{N} ; 149^{\circ} 59^{\prime} 28^{\prime \prime} \mathrm{W}\right)$ in Alaska by one of the author (RK) in July 2014 . The plerocercoids were photographed, excysted in saline solution, fixed with hot water and stored in $80 \%$ ethanol for morphological and molecular evaluation. Terminology of marine ecoregions follows Spalding et al. (2007).

\section{Morphological analysis}

Selected tapeworms were stained and prepared as permanent slides following the procedure described by Hernández-Orts et al. (2015). Additionally, some scolices and pieces of the strobila were embedded in paraffin wax, cross-sectioned (thickness between 12-15 $\mu \mathrm{m}$ ), stained with hematoxylin-eosin and mounted in Canada balsam. Finally, selected plerocercoids, scolices and proglottids were prepared for scanning electron microscopy (SEM) following the procedure described by Kuchta and Caira (2010). Terminology of microtriches follows Chervy (2009).

Drawings were made using a drawing tube attached to an Olympus BX51 microscope (Olympus Corporation, Tokyo, Japan). Measurements were taken using the Olympus QuickPhoto Image-Program. Measurements are expressed in micrometers $(\mu \mathrm{m})$ unless otherwise stated and are presented as the means, followed by the range and number of structures measured in parentheses.

For morphological comparison, type- and voucher material of the following diplogonadic tapeworms was studied (collection numbers, number of specimens studied, hosts 
and site of collection are given in Suppl. Data S1): Bothriocephalus tetrapterus von Siebold, 1848 (type material); B. fasciatus Krabbe, 1865 (type material); B. variabilis Krabbe, 1865 (type material); and Dipl. tetrapterus (vouchers). Additionally, one incomplete specimen of Dipl. violettae without the scolex from the type series, kindly provided by M. V. Yurakhno (Taurida National University, Simferopol, Ukraine), was also examined (see Suppl. Data S1). No material of B. dubius Krabbe 1865 and Dipl. mutabilis Belopolskaya, 1960 was available. Additional diplogonadic specimens identified as members of the genus Diphyllobothrium or Diplogonoporus spp. from pinnipeds and mustelids were obtained from the Harold W. Manter Laboratory of Parasitology, Lincoln, Nebraska, USA (HWHL), the Helminthological Collection of the Institute of Parasitology, Biology Centre of the Czech Academy of Sciences, České Budějovice, Czech Republic (IPCAS), the Natural History Museum of Denmark, Copenhagen, Denmark (ZMUC), the Natural History Museum, London, UK (BMNH), and the National Museum of the Natural History, Smithsonian Institution, Washington, D.C., USA (USNM) (see Suppl. Data S1). Voucher specimens from the present study were deposited in the following collections: Schmalhausen Institute of Zoology NAS of Ukraine, Kyiv (Nos. SAM 0-1-SAM 22-16), USNM (Nos. 1241613) and IPCAS (No. C-682).

\section{Molecular phylogeny}

Six adult cestodes obtained from C. ursinus in the St. Paul Island, two plerocercoids from $O$. gorbuscha in Alaska and one adult from E. lutris in California were selected for molecular studies. Gravid segments from adult worms and small pieces of plerocercoids were used for DNA isolation and sequencing. The remaining parts of the adult specimens were stained and mounted in Canada balsam as hologenophores (see Pleijel et al. 2008), and used for morphological description. Phylogenetic relationships of Diplogonoporus spp. were assessed 
on the basis of two genetic markers: the most densely sampled gene within the genus Diphyllobothrium - cytochrome c oxidase subunit 1 (cox 1$)$ - and nuclear large subunit ribosomal RNA gene (lsrDNA). Genomic DNA was extracted from 96\% ethanol preserved samples using DNeasy Blood and Tissue Kit (Qiagen, Hilden, Germany) according to the manufacturer's protocol. Complete cox 1 gene (1566 bp) was amplified by PCR using the primers Cox1Forward and Cox1Reverse and conditions described in Wicht et al. (2010), partial $l s r$ DNA (D1-D3 domains, $1470 \mathrm{bp}$ ) using the primers LSU5 and 1500R and conditions after Brabec et al. (2012). All products were verified on a 1\% agarose gel, purified through an enzymatic treatment with Exonuclease I and FastAP Alkaline Phosphatase (Thermo Fisher Scientific, Waltham, USA) and Sanger sequenced at GATC Biotech (Konstanz, Germany).

Sequences were assembled using Geneious version 7 (http://www.geneious.com/; Kearse et al. 2012) and deposited in GenBank. cox 1 and lsrDNA alignments were created using the G-INS-i and E-INS-i algorithms in the program MAFFT (Katoh and Standley 2013) implemented in Geneious, respectively.

The phylogenetic relationships were evaluated based on individual gene datasets under maximum likelihood (ML) criteria. Two separate ML analyses were run in Garli 2.0 (Zwickl 2006), in the case of $\operatorname{cox} 1$ data employing dataset partitioning scheme ( $\operatorname{cox} 11 \mathrm{st}$ ) ( $\operatorname{cox} 12 \mathrm{nd})$ (cox1 3rd) and models $(\mathrm{GTR}+\mathrm{I}+\mathrm{G})(\mathrm{TIM}+\mathrm{I})(\mathrm{TIM}+\mathrm{I}+\mathrm{G})$ chosen according to the AICc criterion in PartitionFinder 2.1.1 (Lanfear et al. 2017). ML analysis of $l s r$ DNA utilized TIM+I model. Nodal support values were computed by running 500 bootstrap resamples in Garli. Bootstrap results were summarized in PAUP* version 4.0a150 (Swofford 2002).

\section{Results}


Two types of strobila were observed in freshly obtained material from C. ursinus: (i) 'relaxed', with much longer segments, identical to live specimens; and (ii) 'contracted', with much shorter segments (Fig. 1A). The morphological description is based on 'relaxed' specimens, but a brief description of the contracted worms is also provided. Both types of strobila were morphometrically and molecularly conspecific (see Suppl. Data S3 and Remarks).

\section{Diphyllobothrium tetrapterum (von Siebold, 1848) Baer, 1932 (Figs. 1-4)}

SYNONYMS: Bothriocephalus tetrapterus von Siebold, 1848; Bothriocephalus dubius Krabbe, 1865; Bothriocephalus fasciatus Krabbe, 1865; Bothriocephalus variabilis Krabbe, 1865; Diplogonoporus tetrapterus (von Siebold, 1848) Ariola, 1896; Diplogonoporus septentrionalis Cholodkovsky, 1914; 'Species Nos. 3 and 4' sensu Stunkard (1948); Diplogonoporus mutabilis Belopolskaya, 1960; Diplogonoporus violettae Yurakhno, 1986. TYPe-HOST: harbor seal Phoca vitulina L., 1758 (Pinnipedia: Phocidae) according to Monticelli (1989) and Markowski (1952).

TYPE-LOCALITY: Not known (see Discussion).

AdDitional CONFIRMED HOSTS: (1) Phocidae: bearded seal Erignathus barbatus (Erxleben, 1777), hooded seal Cystophora cristata (Erxleben, 1777), ribbon seal Histriophoca fasciata (Zimmermann, 1783), Harp seal Pagophilus groenlandicus (Erxleben, 1777), spotted seal Phoca largha (Pallas, 1811), ringed seal Pusa hispida (Schreber, 1775); (2) Otariidae: northern fur seal Callorhinus ursinus (L., 1758); Steller sea lion Eumetopias jubatus (Schreber, 1776); (3) Mustelidae: sea otter Enhydra lutris (L., 1758). 
ACCIDENTAL HOSTS: American mink Neovison vison (Schreber, 1777) (Mustelidae); dog

Canis familiaris L., 1758 (Canidae); brown rat Rattus norvegicus (Berkenhout, 1769)

(Muridae).

GeographicAl Distribution: Arctic (Russia, Canada, USA and Greenland), Temperate North Pacific (Japan, Russia, Canada and USA) and Temperate North Atlantic (Iceland) (see Discussion and Suppl. Data S2).

SITE IN DEFINITIVE HOSTS: intestine.

PREVAlENCE AND INTENSITY IN FUR SEAL: 43\% [n = 756]; 4.3-5.4 (Kuzmina et al. 2015).

SECOND INTERMEDIATE HOST: pink salmon Oncorhynchus gorbuscha (Walbaum, 1792)

(Salmoniformes: Salmonidae) (plerocercoids encysted in the stomach wall and liver; new host record).

MATERIAL STUDIED: see Suppl. Data S1.

Description of relaxed cestodes from C. ursinus [based on 18 mounted specimens, numerous histological sections and 15 specimens studied using SEM]. Diphyllobothriidea, Diphyllobothriidae. Worms anapolytic. Strobila 99-165 $(126 ; n=9) \times 2.4-3.2 \mathrm{~mm}(2.6 ; n=$ 11) in posterior portion. Proglottids numerous, approximately $14-20(17 ; n=13)$ per $\mathrm{cm}$ in posterior portion of gravid strobila. Secondary subdivisions of proglottids present (Table 1). Two longitudinal deep grooves over genital atrium (areas free of vitelline follicles) on ventral and dorsal surface of proglottid may be present. Two pairs of excretory canals in medulla on each side of body; internal excretory canal diffuse in first gravid proglottids (midlevel of strobila); external excretory canal diffuse in older (more posterior) gravid proglottids. Longitudinal musculature well developed, formed by small bundles of muscle fibers 39-85 $(55 ; 18)$ wide; maximum distance between muscle bundles in dorsoventral axis representing $16-25 \%$ of width of strobila. 
Scolex oval to lanceolate in lateral view; $1.3-1.7(1.5 ; n=8) \times 1.3-1.6 \mathrm{~mm}(1.4 ; n=$ 4); bothria deep, extending full length of scolex, heart-shaped in lateral view. Neck absent. First proglottids short, narrower than scolex, $\sim 750$ wide, slightly craspedote with sharp posterolateral margins. Proglottids mostly with two sets of genital complexes (diplogonadic; observed in $75 \%$ of studied specimens), but some specimens exclusively with one set of genitalia (monogonadic); exceptionally, more (up to 4 in one contracted specimen) sets per proglottid mostly in immature parts of strobila. Usually, terminal proglottids monogonadic, rarely diplogonadic. Mature diplogonadic proglottids, i.e., with spermatozoa in vas deferens, wider than long, 405-1,139 $(726) \times 1,679-3,246(2,658)(n=21)$; proglottid length/width ratio $1: 1.5-7.9(1: 4.0)(n=21)$; monogonadic proglottids, wider than long, $581-1,139(792)$ $\times 1,679-2,609(2,380)$; proglottid length/width ratio $1: 1.5-4.2(1: 3.1)(n=14)$. Gravid diplogonadic proglottids, i.e., first with eggs in uterus, wider than long, 581-975 (769) × 1,696-2,400 (2,207); proglottid length/width ratio 1:2.1-4.1 (1:2.9) $(n=7)$; gravid monogonadic proglottids, 581-799 $(725) \times 1,696-2,403(2,203)$ wide; proglottid length/width ratio $1: 2.1-4.1(1: 3.1)(n=4)$. Surface of scolex and strobila covered uniformly with capilliform filitriches $\sim 2$ long.

Testes medullary, more or less subspherical, 306-751 $(540 ; \mathrm{n}=8)$ in number, 38-53 $(44 ; n=24)$ in diameter; similar in size in diplogonadic and monogonadic proglottids. In diplogonadic proglottids, testes forming 1 central compact field (between genital pores and uterus) and 2 lateral fields, slightly confluent near anterior margins of proglottids; in monogonadic proglottids, testes arranged in 2 lateral fields; testes reach to extremities of uterine loops and margins of ovary in gravid proglottids.

Vas deferens dorsal, coiled, enlarged distally to form external seminal vesicle. External seminal vesicle muscular, wall 10-13 $(12 ; n=6)$ thick, posterodorsal to cirrus-sac, with its long axis directed dorsoventrally, transversely oval in sagittal section, $75-85(80 ; n=$ 
6) $\times 61-91(73 ; n=6)$; length/width ratio 1:0.8-1.2 (1:0.9; $n=6)$. Cirrus-sac thin-walled, with wall 7-9 $(8 ; n=9)$ thick, pyriform in sagittal section, $180-256(200 ; n=9) \times 100-123$ $(111 ; n=9)$; cirrus-sac length/width ratio 1:0.4-0.6 (1:0.56; $n=9)$; cirrus-sac $133-198(169 ; n$ $=71$ ) wide in dorsoventral view. Cirrus covered with small acicular filitriches $\sim 0.5$ long. Genital pores lateroventral in diplogonadic or medioventral in monogonadic proglottids, with numerous papillae, usually partially covered by posterior margin of anterior segment; at about $13-52 \%(25 \% ; n=49)$ of proglottid length from anterior margin. Genital and uterine pores mostly arranged in longitudinal row in mature and gravid proglottids.

Ovary reticulate, bilobed, asymmetrical, situated ventrally near posterior margin of proglottids, $578-689(629 ; n=9)$ wide; ovarian lobes connected by isthmus lateral to midline in diplogonadic proglottids or in midline in monogonadic proglottids; internal ovarian lobes may slightly overlap themselves medially in diplogonadic proglottids; ovary extending somewhat anterior to proximal uterine loops. Posteromedially, inner (median) ends of ovarian lobes nearly enclosing small Mehlis' gland and oval seminal receptacle. Vagina tubular, thinwalled, ventral, twisted. Vitelline follicles numerous, subspherical, $16-40(23 ; n=209)$ in diameter, cortical, absent in region with reproductive organs; follicles slightly overlap extremities of uterine loops in gravid proglottids, confluent both dorsally and ventrally near anterior and posterior margins of proglottids. Vitelline ducts converge near ovary, forming two main collecting ducts.

Uterine duct tubular, forms numerous tightly coiled loops, filled with eggs. Distal portion of uterus containing fully developed eggs, forms 3-5 transverse loops bilaterally, with anteriormost loops occasionally extending anterior to margin of genital pores. Uterine pore situated ventrally, opening about $34-85(49 ; n=14)$ posterior to vaginal opening. In posterior gravid proglottids, uterus usually occupying about $36-60 \%(49 \% ; n=22)$ of their length. Eggs oval, thick-walled, operculate, unembryonated, size of eggs liberated from uterus of 
unmounted specimens in 70\% ethanol 66-86 (75) $\times 41-52(46)(n=21)$. Shells of eggs slightly pitted.

Brief description of 'contracted' cestodes from $C$. ursinus [based on 16 mounted specimens and 5 specimens studied using SEM].

Strobila $7.1-17.5(11.1 ; n=11) \times 2.8-4.2 \mathrm{~mm}(3.3 ; \mathrm{n}=7)$. About $21-34(27 ; n=14)$ proglottids per $\mathrm{cm}$ in posterior portion of gravid strobila. Secondary subdivisions of proglottids present. Scolex $1.21-1.88(1.45, n=10) \times 1.13-1.53 \mathrm{~mm}(1.27 ; n=7)$. Mature diplogonadic proglottids 360-767 $(552, n=22) \times 2,706-4,460(3,384, n=22)$. Gravid diplogonadic proglottids 380-829 $\mathrm{mm}(568, n=13) \times 2,550-3,235(2,866, n=13)$. Testes $36-55(46, n=101)$ in diameter. Reproductive organs up to 4 sets in young and mature proglottids (Fig. 4F; Table 1). Position of genital and uterine pores highly variable (Fig. 4G), in few proglottids arranged in longitudinal row. Ovary 559-850 $\mathrm{mm}(737, n=22)$ wide. In gravid proglottids, uterus occupying about $30-77 \%(56 \%, n=24)$ of their length.

\section{Remarks}

Von Siebold (1848) briefly described Bothriocephalus tetrapterus from the intestine of an unidentified seal (“Phoca sp.”) from an unknown locality. Monticelli (1889), who studied type material, considered the harbor seal $P$. vitulina as the type-host. Thereafter, Krabbe (1865) superficially described three species of Bothriocephalus with double sets of genital organs as B. dubius from dogs and a brown rat in Iceland, B. variabilis from a hooded seal Cystophora cristata in Iceland, and B. fasciatus from a ringed seal Pusa hispida in Greenland. Later on, these species were transferred to different genera, e.g., Krabbea Blanchard, 1894, Diplogonoporus and Diphyllobothrium Cobbold, 1858, and their validity was repeatedly questioned. Most authors consider them as junior synonyms of Diph. tetrapterum (Baer 1932, 
1962; Wardle et al. 1947; Markowski 1952; Delyamure et al. 1985; Kamo 1999; present study).

We examined type material of B. variabilis and B. fasciatus deposited in Copenhagen (ZMUC). All specimens available were decomposed and only one specimen of B. variabilis represents a diplogonadic form (Fig. 4C). Type material of B. dubius was not found and had been most probably lost. Despite these obstacles, synonymization of all three species described by Krabbe (1865) proposed by previous authors (see above) is accepted herein.

Taxonomic history of Diph. tetrapterum and supposedly conspecific diplogonadic tapeworms from seals has been convoluted. Wardle et al. (1947) listed Dipl. tetrapterus as a synonym of Cordicephalus phocarum (Fabricius, 1780) Wardle, McLeod and Stewart, 1947, but this taxonomic act, along with the validity of Cordicephalus Wardle, McLeod and Stewart, 1947, was not accepted by subsequent authors (e.g. Stunkard 1948; Bray et al. 1994; Kuchta and Scholz 2017).

Stunkard (1948) described two species of tapeworms with double sets of reproductive organs from the intestine of pinnipeds from the St. Paul Island and called them 'Species No. 3' from the intestine of C. ursinus [later identified as Dipl. tetrapterus by Markowski (1952) and Margolis (1956)], and 'Species No. 4' from E. jubatus [synonymized with Dipl. fasciatus by Markowski (1952) and later with Dipl. tetrapterus by Delyamure et al. (1985)].

Markowski (1952) re-examined von Siebold's type material of Dipl. tetrapterus and reported the presence of a short $(\sim 300 \mu \mathrm{m}$ long), narrow neck behind the scolex (see his fig. 34), which is quite unusual in these tapeworms. However, this may be caused by the poor quality of its type material (see Caira et al. 2012). The presence of a very short neck in Diph. tetrapterum has been reported only by few authors (Cholodkovsky 1914; Wardle et al. 1947; Rausch 1964), whereas its absence much more commonly (Stunkard 1948; Margolis 1956; Belopolskaya 1960; Rausch 1964; Delyamure 1966; Yurakhno 1986; present study). 
Belopolskaya (1960) described Dipl. mutabilis from P. vitulina found in the Whale Bay in the northwestern Sea of Japan. In her very superficial description, she differentiated Dipl. mutabilis from the other species of Diplogonoporus by the unusual variation of the number of reproductive organs per proglottid (from 2 to 5), and by the different positions of genital and uterine pores opening separately on the surface (see figs. 1 and 3 in Belopolskaya 1960). Shults (1982) considered Dipl. mutabilis as species inquirenda because of the high variability in the number of sets of reproductive organs, whereas Kamo (1999) synonymized Dipl. mutabilis with Dipl. tetrapterus. This synonymy is also accepted in the present study.

The most detailed morphological revision of diplogonadic diphyllobothriids was made by Rausch (1964) who redescribed Dipl. tetrapterus from the sea otter E. lutris, American mink Neovison vison, fur seal C. ursinus and Steller sea lion Eumetopias jubatus in Alaska. Examination of Rausch's (1964) material in the present study did not reveal any morphological differences between his specimens and our newly collected material, although the worms from E. lutris are larger than the specimens from C. ursinus (Fig. 4D, see Suppl. Data S3).

The most recently described species, Dipl. violettae, was found in E. jubatus from Karaginsky Bay (Bering Sea), Kamchatka, Russia (Yurakhno 1986). This species was distinguished from Dipl. tetrapterus and other congeneric species by the possession of a larger scolex and eggs, and by the different definitive hosts (Steller sea lions). However, only a single specimen (holotype), which has a markedly larger strobila, scolex and eggs than remaining tapeworms of the type series, was used by Yurakhno (1986) for description of Dipl. violettae. In addition, the size of the body and other structures including the scolex may vary considerably even within the same population (see Hernández-Orts et al. 2015 and references therein). In fact, examination of available material of Dipl. violettae in the present study did not show any reliable morphological differences and most of the morphometric characters 
overlap with those of Diph. tetrapterum (see Table 2; Suppl. Data S3). Therefore, we agree with the conclusion of Kuzmina et al. (2015) who considered Dipl. violettae as a junior synonym of Diph. tetrapterum. Finally, Waeschenbach et al. (2017) confirmed synonymization of the genus Diplogonoporus with Diphyllobothrium, transferred Diph. tetrapterum to Diphyllobothrium, but considered it as a species incertae sedis.

\section{First description of plerocercoids of Diphyllobothrium tetrapterum}

Description [based on 2 specimens observed alive and studied using SEM]: Plerocercoids encysted in large white cysts in liver and stomach wall (Fig. 3E, F). After liberation from cysts, plerocercoids highly motile, 15-23 mm long (depending on state of elongation or contraction - Suppl. Video S4), with retracted scolex. After fixation with hot water, plerocercoids $\sim 15 \mathrm{~mm}$ long, with heart-shaped scolex $\sim 1 \times 1 \mathrm{~mm}$ in size, possessing 2 deep bothria (Fig. 2G). Surface covered with capiliform filitriches ( $\sim 5$ long), interspersed with isolated uncinate spinitriches ( $\sim 1.5$ long) on apical part of scolex; posterior part of scolex and rest of plerocercoid covered with numerous capiliform filitriches ( 2 long) (Figs. 2H, I, M).

\section{Phylogenetic relationships}

The present phylogenetic analyses based on $\operatorname{cox} 1$ and $l s r$ DNA confirmed that all nine specimens of Diph. tetrapterum analyzed are conspecific and form a separate, well defined clade that is sister to a clade of freshwater diphyllobothriids consisting of Ligula spp. and Dibothriocephalus spp. Diphyllobothrium tetrapterum does not group with another diplogonadic species, Diph. balaenopterae, which is found in a more basal position forming a sister lineage to Diph. stemmacephalum (Fig. 5; see also Waeschenbach et al. 2017). 


\section{Discussion}

The presence of multiple copies of genital organs per one proglottid is a typical character of several diphyllobothriids. These polygonadic forms are known in species of Ligula Bloch, 1782 (those previously placed in Digramma Cholodkovsky, 1915 - see Dubinina 1980), Diplogonoporus (now Diphyllobothrium) and Tetragonoporus Skryabin, 1961 (previously placed to the genera Multiductus Clarke, 1962 and Polygonoporus Skryabin, 1967 - see Kuchta and Scholz 2017); from two to 14 sets of genitalia may be present in one proglottid in these species. Extreme case of multiplication of gonads exists in Baylisia Markowski, 1952, in which as many as 307 genital complexes per single proglottid were observed (Yurakhno, 1992). However, the number of the genital complexes per proglottid may vary among specimens of the same species or even within a single strobila (Baer 1932; Delyamure 1955). In contrast, Diph. balaenopterae from whales and humans have almost exclusively diplogonadic proglottids (Rausch 1964).

The variability in the number of genital complexes per proglottid in Diph. tetrapterum from different definitive hosts was reported by several authors (Stunkard 1948; Markowski 1952; Margolis 1956; Rausch 1964; Delyamure et al. 1985; Kamo 1999) and was confirmed in the present study (Table 1). In young and gravid proglottids of Diph. tetrapterum from $C$. ursinus, up to 4 sets of reproductive organs were observed (Fig. 4F; Table 1). Similarly, a high variability was observed in the position of the genital and uterine pores (Fig. 4G). Molecular data confirmed conspecificity of monogonadic and diplogonadic specimens (Fig. 5). They also demonstrate that the diplogonadic forms have arisen on several independent occasions within the family Diphyllobothriidae, as shown on the present phylogenetic tree (Fig. 5; see also Waeschenbach et al. 2017): during the anageneses of both Ligula interrupta 
Rudolphi 1810 and Diph. balanopterae, and at least once during the evolution of Diph.

tetrapterum. Diplogonadic forms were also found in a few specimens of the genus

Dibothriocephalus or within Diph. stemmacephalum (Yanagida et al. 2010). As a result, the previously established genus Diplogonoporus, as well as Digramma, which is currently considered as a synonym of Ligula (see Kuchta and Scholz 2017), is not natural and has been correctly synonymized by Waeschenbach et al. (2017).

Total length was used to differentiate species of diplogonadic diphyllobothriids (see Yurakhno 1986), but this character as well as most of other morphometric characteristics does not seem to be suitable for species identification because of the high intraspecific variability of diphyllobothriid tapeworms (Hernández-Orts et al. 2015; Kuchta and Scholz 2017). Moreover, the size of diphyllobothriids may depend on the host species, its size, physiological state, intensity of infection and fixation methods (Baer et al. 1967; Andersen 1972; Halvorsen and Andersen 1974; Hernández-Orts et al. 2015; present study). The size of Diph. tetrapterum is also variable, ranging from $99 \mathrm{~mm}$ in mature specimens from $C$. ursinus to more than $1.8 \mathrm{~m}$ in specimens from E. lutris (see Suppl. Data S3). Extreme variability was also observed in the size of mature proglottids of Diph. tetrapterum from different species of marine mammals (Fig. 4). Consequently, available evidence suggests that the size of the strobila and proglottids has a limited taxonomic value to distinguish diphyllobothriids.

The present study has also revealed conspicuous differences in the shape of strobilae of tapeworms from the same host and two markedly different morphotypes were found. Most specimens were contracted and their proglottids were short and wide (proglottid length/width ratio: $1: 4-12$ ) (Fig. 1A), whereas some tapeworms were more relaxed and had more elongate proglottids (ratio 1 : 1.5-8) (Figs. 1C, D); see Suppl. Data S3). Molecular data provide evidence that both morphotypes are conspecific. 
Variations in the scolex and strobila shape of diphyllobothriid tapeworms can depend critically on the method of relaxation and fixation (Rausch 1954; Kuchta and Scholz 2017), even though examples of a high intraspecific variability exist among diphyllobothriid tapeworms (e.g., A. pacificus; see Hernández-Orts et al. 2015). All cestodes collected from the northern fur seals in Alaska were fixed in hot $\left(>90^{\circ} \mathrm{C}\right)$ tap water for about $10 \mathrm{sec}$ and stored in $70 \%$ ethanol (see Kuzmina et al. 2015 for details), thus the great variability in the shape of the strobila should not be a consequence of different fixation procedures. A similar observation was made by Rausch (1964), who reported that some strobilae became strongly contracted during fixation in $10 \%$ formalin.

The size and shape of the eggs may serve as a suitable tool to distinguish some species of diphyllobothriid cestodes (Leštinová et al. 2016), even though the size of the eggs of diphyllobothriid tapeworms may vary, depending on the size and type of definitive hosts and on the intensity of infection (Andersen and Halvorsen 1978; Yazaki et al. 1990). In diplogonadic tapeworms from pinnipeds, the size of the eggs has been considered a suitable feature to differentiate species (e.g. Belopolskaya 1960; Delyamure et al. 1985; Yurakhno 1986). Rausch (1964) distinguished two groups (forms) on the basis of egg dimensions: one group with small eggs $(40-55 \times 15-40 \mu \mathrm{m})$ and the other with relatively large $(61-78 \times 36-50$ $\mu \mathrm{m})$ eggs. This marked difference in the size of the eggs was also observed in the present study (Table 2; Suppl. Data S3). Interestingly, smaller eggs were reported from tapeworms found in phocids (earless seals), whereas larger eggs were found in cestodes from otariids (eared seal) and mustelids (sea otters) (Table 2; Suppl. Data S3).

The complete life cycle of Diph. tetrapterum is still unknown, but it is expected to include marine copepods as the first intermediate hosts, marine fishes as the second intermediate hosts and fish-eating mammals as the definitive hosts (Kuchta and Scholz 2017). The present study provides the first evidence that salmonids may serve as second (fish) 
intermediate hosts, specifically pink salmon O. gorbuscha in Alaska, in which plerocercoids of Diph. tetrapterum were found in two occasions. However, salmonids comprise a small proportion in the diet of the northern fur seal (only about 4\%; see Sinclair et al. 2008). Since the prevalence of Diph. tetrapterum in fur seals is relative high (43\%; Kuzmina et al. 2015), it is very likely that other fishes that are commonly consumed by fur seals, e.g. Alaska pollock Gadus chalcogrammus Pallas or Atka mackerel Pleurogrammus monopterygius (Pallas) (Sinclair et al. 2008), are potential candidates as second intermediate hosts of Diph. tetrapterum. Since O. gorbuscha is not distributed along the North Atlantic Ocean (see Page and Burr 1991), where Diph. tetrapterum occurs commonly (Fig. 6), other salmonids or marine teleosts must serve as fish hosts.

Marine aquatic carnivores including otariids (one sea lion species and one fur seal), phocids (seven species) and rarely mustelids (sea otter) are supposed to serve as the principal definitive hosts for Diph. tetrapterum (Suppl. Data S2). Interestingly, odobenids (walrus) have never been reported as hosts of any diplogonadic tapeworm species (Delyamure 1955; Delyamure et al. 1985; Yurakhno 1998; Kamo 1999; Felix 2013; present study). Diph. tetrapterum displays a low degree of host specificity (euryxeny), and has been reported also from terrestrial mammals such as mustelids (American mink), canids (domestic dog) and even murids (brown rat) (Krabbe 1865; Rausch 1964; Suppl. Data S2). However, these mammals apparently represent only accidental hosts.

Based on an exhaustive literature search and our own results, the geographical distribution of Diph. tetrapterum seems to be restricted to the Northern Hemisphere, with most of the records from the Arctic (off Canada, Greenland, Iceland, Russia, and USA) and Cold Temperate Northeast and Northwest Pacific (off Canada, Japan, Russia, and USA) (Fig. 6). The southernmost record is represented by the finding of Diph. tetrapterum in E. lutris nereis from Monterey Bay, California, USA (Young et al. 2017). Records of Diph. 
tetrapterum from the North Atlantic are scarce and are limited to the coast of Iceland (Northern European Seas), Greenland and the Arctic Coast of Canada.

The type locality of Diph. tetrapterum is unknown, although Delyamure (1955) stated to be somewhere off northern Europe. However, the same author (Delyamure 1966) later speculated that the specimens described by von Siebold (1848) had been found in the Greenland Sea. To our knowledge, there are no records of Diph. tetrapterum off mainland Europe and the United Kingdom, although the intestinal helminth fauna of several species of seals have been studied (e.g. Delyamure et al. 1985; Heide-Jorgensen et al. 1992). Diph. tetrapterum has never been reported from the tropics or from the Southern Hemisphere (e.g., Yurakhno and Maltsev 1997; Felix 2013), even though numerous species of otariids and phocids occur there, especially in the Southern Ocean (e.g. Berta and Churchill 2012). This is in sharp contrast with the worldwide distribution area of another seal tapeworm, Adenocephalus pacificus Nybelin, 1931, a common parasite of otariids which may occur sympatrically with Diph. tetrapterum in C. ursinus (see Kuzmina et al. 2015), but which also occurs in sea lions and fur seals on both hemispheres (Hernández-Orts et al. 2015).

\section{Acknowledgements}

Valuable comments of two anonymous reviewers are much appreciated. The authors are indebted to Michail V. Yurakhno (Ukraine) and Colleen Young (Canada) who kindly provided valuable material for the present study, and to curators of numerous collections. The authors also thank to Eugene T. Lyons (Kentucky University, USA) and Terry R. Spraker (Colorado State University, USA) for their valuable help in field work on the St. Paul Island to one of co-authors (TK). Visits to the museums were supported by the SYNTHESYS 
program of the European Communities (projects Nos. GB-TAF-735 and 926, DK-TAF-4500). This study was also supported by the Czech Science Foundation (projects P506/12/1632) and the Institute of Parasitology, Biology Centre of the Czech Academy of Sciences (RVO: 60077344).

\section{References}

Andersen, K.I. 1972. Studies of the helminth fauna of Norway XXI: the influence of population size (intensity of infection) on morphological characters in Diphyllobothrium dendriticum Nitzsch in the golden hamster (Mesocrisetus auratus Waterhouse). Norw. J. Zool. 20: 1-7.

Andersen, K.I., and Halvorsen, O. 1978. Egg size and form as taxonomic criteria in Diphyllobothrium. Parasitology. 76: 229-240. doi:10.1017/S0031182000047818

Baer, J.G. 1932. Contribution à l'étude des cestodes de cétacés. Rev. Suisse Zool. 39: 195228.

Baer, J.C. 1962. Cestoda. In Zoology of Iceland. Vol. 2, Pt. 12. Munksgaard, Copenhagen.

Baer, J.G., Miranda, H., Fernandez, W., and Medina, T.J. 1967. Human diphyllobothriasis in Peru. Z. Parasitenkd. 28: 227-289, doi:10.1007/BF00260267.

Belopolskaya, M.M. 1960. The helminth fauna of the harbour seal (Phoca vitulina largha Pall.). Vestn. Leningr. Univ. 3: 113-121 (in Russian).

Berta, A., and Churchill, M. 2012. Pinniped taxonomy: review of currently recognized species and subspecies, and evidence used for their description. Mammal Rev. 42: 207-234. doi:10.1111/j.1365-2907.2011.00193.x.

Brabec, J., Scholz, T., Král’ová-Hromadová, I., Bazsalovicsová, E., and Olson, P.D. 2012. Substitution saturation and nuclear paralogs of commonly employed phylogenetic 
markers in the Caryophyllidea, an unusual group of non-segmented tapeworms

(Platyhelminthes). Int. J. Parasitol. 42: 259-267. doi:10.1016/j.ijpara.2012.01.005.

Bray, R.A., Jones, A., and Andersen, K.I. 1994. Order Pseudophyllidea Carus, 1893. In Keys to the Cestode Parasites of Vertebrates. Edited by L.F. Khalil, A. Jones, and R.A. Bray. CABI International. University Press, Cambridge. pp. 205-247.

Caira, J.N., Jensen, K., and Barbeau, E. (Editors), 2012. Global Cestode Database. World Wide Web electronic publication. www.tapewormdb.uconn.edu. Accessed January 2017.

Chervy, L. 2009. Unified terminology for cestode microtriches: a proposal from the International Workshops on Cestode Systematics in 2002-2008. Folia Parasitol. 56: 199-230. doi:10.14411/fp.2009.025

Cholodkovsky, N. 1914. Cestodes nouveaux ou peu connus. Troisième série. Annu. Mus. Zool. Acad. Sci. St. Petersb. 8: 516-523.

Delyamure, S.L. 1955. Helminthofauna of Marine Mammals (Ecology and Phylogeny). Izdat. Ak. Nauk SSSR, Moscow (in Russian).

Delyamure, S.L. 1966. Morphological and anatomical investigation of Diplogonoporus tetrapterus (Siebold, 1848), which parasitizes Pinnipedia of the Greenland Sea. Problemy Parazitol. 1966: 39-43 (in Russian).

Delyamure, S.L., Skryabin, A.S., and Serdyukov, A.M. 1985. Essentials of Cestodology. Diphyllobothriata - Flatworm Parasites of Man, Mammals and Birds, vol. XI. Nauka, Moscow (in Russian).

Dubinina, M.N. 1980. Tapeworms (Cestoda, Ligulidae) of the Fauna of the USSR. American Publishing Company. Washington D.C.

Felix, J.R. 2013. Reported Incidences of Parasitic Infections in Marine Mammals from 1892 to 1978. Zea Books, Lincoln, Nebraska. 
Halvorsen, O., and Andersen, K. 1974. Some effects of population density in infections of Diphyllobothrium dendriticum (Nitzsch) in golden hamster (Mesocricetus auratus Waterhouse) and common gull (Larus canus L.). Parasitology. 69: 149-160. doi:10.1017/S0031182000047995.

Heide-Jorgensen, M.P., Harkonen, T., Dietz, R., and Thompson, P.M. 1992. Retrospective of the 1988 European seal epizootic. Dis. Aquat. Org. 13: 37-62.

Hernández-Orts, J.S., Scholz, T., Brabec, J., Kuzmina, T., and Kuchta, R. 2015. High morphological plasticity and global geographical distribution of the Pacific broad tapeworm Adenocephalus pacificus (syn. Diphyllobothrium pacificum): molecular and morphological survey. Acta Trop. 149: 168-178. doi:10.1016/j.actatropica.2015.05.017.

Kamo, H. 1999. Guide to Identification of Diphyllobothriid Cestodes. Gendai Kikaku, Tokyo (in Japanese).

Katoh, K., and Standley, D.M. 2013. MAFFT multiple sequence alignment software version 7: improvements in performance and usability. Mol. Biol. Evol. 30: 772-780. doi:10.1093/molbev/mst010.

Kearse, M., Moir, R., Wilson, A., Stones-Havas, S., Cheung, M., Sturrock, S., Buxton, S., Cooper, A., Markowitz, S., Duran, C., Thierer, T., Ashton, B., Mentjies, P., and Drummond, A. (2012). Geneious Basic: an integrated and extendable desktop software platform for the organization and analysis of sequence data. Bioinformatics. 28: 16471649.

Krabbe, H. 1865. Helminthologiske Undersögelser i Danmark og paa Island, med saerligt Hensyn til Blaereomlidelserne paa Island. Kgl. Danske Videnskab. Selskab. Shrifter Naturvidenskab. Math. Afdel. 7: 347-408. (in Danish). 
Kuchta, R., and Caira, J.N. 2010. Three new species of Echinobothrium (Cestoda:

Diphyllidae) from Indo-Pacific stingrays of the genus Pastinachus (Rajiformes:

Dasyatidae). Folia Parasitol. 57: 185-196. doi:10.14411/fp.2010.025.

Kuchta, R., and Scholz, T. 2017. Diphyllobothriidea Kuchta, Scholz, Brabec and Bray, 2008. In Planetary Biodiversity Inventory (2008-2017): Tapeworms from Vertebrate Bowels of the Earth. Edited by J. N. Caira and K. Jensen. University of Kansas, Natural History Museum, Special Publication No. 25, Lawrence, KS, USA, pp. 167-189.

Kuzmina, T.A., Hernández-Orts, J.S., Lyons, E.T., Spraker, T.R., Kornyushyn, V.V., and Kuchta, R. 2015. The cestode community in northern fur seals (Callorhinus ursinus) on St. Paul Island, Alaska. Int. J. Parasitol. Parasites Wildl. 4: 256-263. doi:10.1016/j.ijppaw.2015.04.007.

Lanfear, R., Frandsen, P.B., Wright, A.M., Senfeld, T., and Calcott, B. 2017. PartitionFinder 2: new methods for selecting partitioned models of evolution for molecular and morphological phylogenetic analyses. Mol. Biol. Evol. 34: 772-773. doi:https://doi.org/10.1093/molbev/msw260

Leštinová, K., Soldánová, M., Scholz, T., and Kuchta, R. 2016. Eggs as a suitable tool for species diagnosis of causative agents of human diphyllobothriosis (Cestoda). PLoS Negl. Trop. Dis. 10: e0004721. doi:10.1371/journal.pntd.0004721.

Lönnberg, E. 1892. Anatomische Studien über Skandinawische Cestoden II. Zwei Parasiten aus Walfischen und Zwei aus Lämna cornubica. Bih. Kgl. Svanska Vetenskaps-Akad. Handl. 24: 4-28.

Margolis, L. 1956. Parasitic helminths and arthropods from Pinnipedia of the Canadian Pacific coast. J. Fish. Res. Bd. Can. 13: 489-505. doi:10.1139/f56-030.

Markowski, S. 1952. The cestodes of pinnipeds in the Arctic and other regions. J. Helminthol. 26: 171-214. doi:10.1017/S0022149X00032612. 
Monticelli, F.S. 1889. Notes on some Entozoa in the collection of the British Museum. Proc.

Zool. Soc. Lond. 3: 321-325.

Page, M.L., and Burr, B.M. 1991. A field guide to freshwater fishes of North America North of Mexico. Houghton Mifflin Company, Boston.

Pleijel, F., Jondelius, U., Norlinder, E., Nygren, A., Oxelman, B., Schander, C., Sundberg, P., and Thollesson, M. 2008. Phylogenies without roots? A plea for the use of vouchers in molecular phylogenetic studies. Mol. Phylogenet. Evol. 48: 369-371. doi:10.1016/j.ympev.2008.03.024.

Rausch, R.L. 1954. Studies on the helminth fauna of Alaska. XXI. Taxonomy, morphological variation, and ecology of Diphyllobothrium ursi n. sp. provis. on Kodiak Island. J. Parasitol. 40: 540-563. doi:10.2307/3274021.

Rausch, R.L. 1964. Studies on the helminth fauna of Alaska. XLI. Observations on cestodes of the genus Diplogonoporus Lönnberg, 1892 (Diphyllobothriidae). Can. J. Zool. 42: 1049-1069. doi:10.1139/z64-103.

Scholz, T., and Kuchta, R. 2016. Fish-borne, zoonotic cestodes (Diphyllobothrium and relatives) in cold climates: a never-ending story of neglected and (re)-emergent parasites. Food Waterborne Parasitol. 4: 23-38. doi:10.1016/j.fawpar.2016.07.002.

Shults, L.M. 1982. Helminths of the spotted seal, Phoca largha, from the Bering Sea. J. Wildl. Dis. 18: 59-62. doi:10.7589/0090-3558-18.1.59.

von Siebold, C.T.E. 1848. Lehrbuch der vergleichenden Anatomie der wirbellosen Thiere. Erster Theil, Wirbellose Thiere. Verlag von Veit, Berlin.

Sinclair, E.H., Vlietstra, L.S. Johnson, D.S. Zeppelin, T.K., Byrd, G.V., Springer, A.M., Ream, R.R., and Hunt Jr., G.L. 2008. Patterns in prey use among fur seals and seabirds in the Pribilof Islands. Deep-Sea Res. II. 55: 1897-1918. 
Spalding, M.D., Fox, H.E., Allen, G.R., Davidson, N., Ferdaña, Z.A., Finlayson, M.,Halpern, B.S., Jorge, M.A., Lombana, A., Lourie, S.A., Martin, K.D., McManus, E.,Molnar, J., Recchia, C.A., and Robertson, J. 2007. Marine ecoregions of the world: a bioregionalization of coastal and shelf areas. Bioscience. 57: 573-583. doi:10.1641/B570707.

Stunkard, H.W. 1948. Pseudophyllidean cestodes from Alaskan pinnipeds. J. Parasitol. 34: 211-228. doi:10.2307/3273267.

Swofford, D.L. 2002. PAUP* . Phylogenetic Analysis Using Parsimony (*and other Methods). Version 4. Sinauer Associates, Sunderland, Massachusetts.

Waeschenbach A., Brabec J., Scholz T., Littlewood D.T.J., and Kuchta R. 2017. The catholic taste of broad tapeworms - multiple routes to human infection. Int. J. Parasitol. (in press). https://doi.org/10.1016/j.ijpara.2017.06.004.

Wardle, R.A., McLeod, J.A., and Stewart, I.E. 1947. Lühe’s “Diphyllobothrium” (Cestoda). J. Parasitol. 33: 319-330. doi:10.2307/3273360.

Wicht, B., Yanagida, T., Scholz, T., Ito, A., Jiménez, J.A., and Brabec, J. 2010. Multiplex PCR for differential identification of broad tapeworms (Cestoda: Diphyllobothrium) infecting humans. J. Clin. Microbiol. 48: 3111-3116. doi:10.1128/JCM.00445-10.

Yamasaki, H., Kumazawa, H., Sekikawa, Y., Oda, R., Hongo, I., Tsuchida, T., Saito, N., Morishima, Y., and Sugiyama, H. 2016. First confirmed human case of Diphyllobothrium stemmacephalum infection and molecular verification of the synonymy of Diphyllobothrium yonagoense with D. stemmacephalum (Cestoda: Diphyllobothriidea). Parasitol. Int. 65: 412-421. doi:10.1016/j.parint.2016.06.003 Yamasaki, H., Ohmae, H., and Kuramochi, T. 2012. Complete mitochondrial genomes of Diplogonoporus balaenopterae and Diplogonoporus grandis (Cestoda: 
Diphyllobothriidae) and clarification of their taxonomic relationships. Parasitol. Int. 61: 260-266. doi:10.1016/j.parint.2011.10.007.

Yanagida, T., Matsuoka, H., Kanai, T., Nakao, M., and Ito, A. 2010. Anomalous segmentation of Diphyllobothrium nihonkaiense. Parasitol. Int. 59: 268-270. doi:10.1016/j.parint.2009.12.006

Yazaki, S., Fukumoto, S., Maejima, J., and Miyahara, M. 1990. Comparative observations of Diphyllobothrium pacificum from a man and from fur seals. J. Yonago Med. Assoc. 41: 204-210 (In Japanese).

Young C., Miller, M.A., Kuchta R., Brabec J., Newsome, S.D., and Dailey, M. 2017. First report of adult tapeworm (Cestoda: Diphyllobothriidea) in a southern sea otter (Enhydra lutris nereis). J. Wildlife Dis. (in press). https://doi.org/10.7589/2017-01-020.

Yurakhno, M.V. 1986. New species of cestodes Diplogonoporus violettae sp. n., (Cestoda, Diphyllobothriidae), a parasite of Eumetopias jubatus Schreb. from the Bering Sea. Parazitologiya. 20: 39-45 (in Russian).

Yurakhno, M. V. 1992. On the taxonomy and phylogeny of some groups of cestodes of the order Pseudophyllidea. Parazitologiya. 26: 449-460 (in Russian).

Yurakhno M.V., and Maltsev, V.N. 1997. An infection of seals from Antarctica with cestodes. Parazitologiya. 31: 81-89 (in Russian).

Zwickl, D.J. 2006. Genetic algorithm approaches for the phylogenetic analysis of large biological sequence datasets under the maximum likelihood criterion. Ph.D. thesis, School of Biological Sciences, The University of Texas at Austin, Austin, Texas. 
Figure captions

Fig. 1. Line drawings of Diphyllobothrium tetrapterum ex Callorhinus ursinus from St. Paul Island, Alaska. Whole contracted worm, ventral view, (A); Relaxed scoleces, lateral view (B); Mature relaxed monogonadic proglottids, ventral view (C); Mature relaxed diplogonadic proglottids, ventral view (D); Reproductive organs, ventral view (E). Note: vitelline follicles omitted on the right side of proglottids. Abbreviations: cs, cirrus-sac; eg, egg; es, external seminal vesicle; mg, Mehlis' gland; ov, ovary; te, testes; ut, uterus; va, vagina; vd, viteloduct; vi, vitelline follicles.

Fig. 2. Scanning electron micrographs of Diphyllobothrium tetrapterum ex Callorhinus ursinus from St. Paul Island, Alaska (A-G, K-M, O-R) and plerocercoid ex Onchorhynchus gorbuscha from Alaska (H-J, N, S). Scolex (A-G); surface of scolex and strobila covered with uniform capilliform filitriches (L, M, O); surface of the plercocercoid covered with capiliform filitriches, apical part of scolex also with interspersed, isolated uncinate spinitriches $(J)$, posterior part of the scolex and rest of plerocercoid covered with numerous capilliform filitriches $(\mathrm{N}, \mathrm{S})$. Gravid diplogonadic proglottids $(\mathrm{K})$ with detail of the cirrus covered with acicular filitriches (Q). Posterior part of strobila with monogonadic proglottids (P) with detail of the genital pore (Q).

Fig. 3. Photomicrographs of histological sections of Diphyllobothrium tetrapterum ex Callorhinus ursinus from St. Paul Island, Alaska (A-D) and pleroceroids in situ of the liver (E) and stomach wall (F) Oncorhynchus gorbuscha with excysted specimens. Abbreviations: cs, cirrus-sac; es, external seminal vesicle; gp, genital pore; ut, uterus; va, vagina. 
Fig. 4. Schematic drawings of proglottids of Diphyllobothrium tetrapterum from different marine mammals hosts. Gravid proglottids (A-E same magnification) ex Callorhinus ursinus from Alaska (A); ex Eumetopias jubatus from Alaska (HWHL 31751) (B) and from the Bering Sea, Arctic (C); ex Phoca vitulina from Greenland (ZMUC, uncatalogued - type material of Bothriocephalus variabilis) (D); ex E. jubatus from the Bering Sea, Russia (from type series of Diplogonoporus violettae) (E). Ventral view of immature diplo-, triplo- or tetraplogonadic segments (F) and positions of genital and uterine pores opening in gravid diplogonadic segments $(\mathrm{G})$ ex C. ursinus from Alaska. Note: fg, female gonopore; ga, genial atrium; mg, male gonopore; up, uterine pore.

Fig. 5. Maximum likelihood estimates of the phylogenetic relationships of Diphyllobothrium tetrapterum. Individual genes were evaluated separately. cox 1 dataset (up) was analysed under a partitioning scheme and models $(\mathrm{GTR}+\mathrm{I}+\mathrm{G})(\mathrm{TIM}+\mathrm{I})(\mathrm{TIM}+\mathrm{I}+\mathrm{G})$ corresponding to the codon positions, $l s r$ DNA (down) utilized TIM+I model. Nodal values show bootstrap support. GenBank accession numbers are shown behind the species names.

Fig. 6. Geographical distribution of Diphyllobothrium tetrapterum on the North Hemisphere. 
Table 1 Number of genital organs per segment in Diphyllobothrium tetrapterum ex Callorhinus ursinus from St. Paul Island, Alaska.

\begin{tabular}{|c|c|c|c|c|c|c|c|c|c|c|c|c|}
\hline \multirow[t]{2}{*}{$\begin{array}{l}\text { Tapeworm } \\
\text { No. }\end{array}$} & \multirow{2}{*}{$\begin{array}{l}\text { Strobila } \\
\text { length } \\
(\mathrm{mm})\end{array}$} & \multirow{2}{*}{$\begin{array}{l}\text { No. of } \\
\text { segments } \\
\text { (No. secondary } \\
\text { subdivisions) }\end{array}$} & \multirow{2}{*}{$\begin{array}{l}\text { First } \\
\text { genital } \\
\text { anlagens }\end{array}$} & \multicolumn{4}{|c|}{$\begin{array}{l}\text { No. of sets of rudimentary reproductive } \\
\text { organs per immature segment }\end{array}$} & \multirow{2}{*}{$\begin{array}{l}\text { First } \\
\text { gravid } \\
\text { proglottids }\end{array}$} & \multicolumn{4}{|c|}{$\begin{array}{l}\text { No. of sets of reproductive } \\
\text { organs per mature segment }\end{array}$} \\
\hline & & & & 1 & 2 & 3 & 4 & & 1 & 2 & 3 & 4 \\
\hline \multicolumn{13}{|l|}{ Relaxed } \\
\hline 1 & 99 & $230(61)$ & 93 & $67(84 \%)$ & $13(16 \%)$ & - & - & 149 & $43(44 \%)$ & $54(56 \%)$ & - & - \\
\hline 2 & 104 & $279(38)$ & 88 & - & $78(100 \%)$ & - & - & 153 & $47(33 \%)$ & $94(67 \%)$ & - & - \\
\hline 3 & 106 & $192(35)$ & 93 & - & $76(100 \%)$ & - & - & 146 & - & $51(100 \%)$ & - & - \\
\hline 4 & 115 & $251(40)$ & 82 & $82(53 \%)$ & $73(47 \%)$ & - & - & 208 & - & $46(100 \%)$ & - & - \\
\hline 5 & 116 & $229(50)$ & 79 & - & $106(100 \%)$ & - & - & 161 & $19(23 \%)$ & $63(77 \%)$ & - & - \\
\hline 6 & 139 & $268(34)$ & 80 & - & $55(100 \%)$ & - & - & 122 & $24(15 \%)$ & $139(85 \%)$ & - & - \\
\hline 7 & 139 & 277 (76) & 144 & $61(100 \%)$ & - & - & - & 185 & $120(100 \%)$ & - & - & - \\
\hline 8 & 149 & $284(40)$ & 119 & $56(100 \%)$ & - & - & - & 163 & $139(100 \%)$ & - & - & - \\
\hline 9 & 165 & $373(51)$ & 141 & $92(100 \%)$ & - & - & - & 221 & $179(100 \%)$ & - & - & - \\
\hline \multicolumn{13}{|l|}{ Contracted } \\
\hline 10 & 90 & 214 & 78 & - & $139(100 \%)$ & - & - & 190 & - & $24(100 \%)$ & - & - \\
\hline 11 & 99 & 399 & 124 & $1(1 \%)$ & $117(99 \%)$ & - & - & 235 & $13(2 \%)$ & $166(98 \%)$ & - & - \\
\hline 12 & 101 & 261 & 92 & $1(1 \%)$ & $175(99 \%)$ & - & - & 222 & $3(7 \%)$ & $40(93 \%)$ & - & - \\
\hline 13 & 109 & 160 & 91 & $29(54 \%)$ & $25(46 \%)$ & - & - & 139 & $3(12 \%)$ & $21(88 \%)$ & - & - \\
\hline 14 & 109 & 354 & 82 & - & $136(100 \%)$ & - & - & 209 & $7(5 \%)$ & $144(95 \%)$ & - & - \\
\hline 15 & 118 & 425 & 118 & - & $58(42 \%)$ & $66(48 \%)$ & $15(10 \%)$ & 235 & - & $186(90 \%)$ & $18(9 \%)$ & $3(1 \%)$ \\
\hline
\end{tabular}

"The number of secondary subdivision of primarily segments could not be estimated reliably in contracted tapeworms 
Table 2 Measurements (in micrometres) of the eggs of Diphyllobothrium tetrapterum from different marine mammals taken by the present authors.

\begin{tabular}{|c|c|c|c|c|c|}
\hline Definitive host & Locality & No. of eggs measured & Range (mean) & Coll. No. & Source of material \\
\hline \multicolumn{6}{|l|}{ Mustelidae } \\
\hline \multirow{2}{*}{ Enhydra lutris } & Aleutian Islands, Alaska & 25 & $64-79 \times 44-52(71 \times 49)$ & USNM 1356137 & Rausch (1964) \\
\hline & Gulf of Alaska & 25 & $61-73 \times 45-50(68 \times 47)$ & USNM 1381986 & Margolis et al. (1997) \\
\hline \multicolumn{6}{|l|}{ Otariidae } \\
\hline Callorhinus ursinus & St. Paul Island, Alaska & 21 & $66-86 \times 41-52(75 \times 46)$ & SAM 7-32 & Present study \\
\hline $\begin{array}{l}\text { Eumatopias jubatus } \\
\text { Phocidae }\end{array}$ & Kamchatka, Russia & 25 & $64-75 \times 45-50(70 \times 48)$ & IPCAS C-683 & Present study** \\
\hline Phoca vitulina & Qeqertarsuaq, Greenland & 21 & $49-54 \times 37-40(51 \times 39)$ & ZMUC * & Krabbe $(1865) * *$ \\
\hline Pusa hispida & Greenland & 21 & $53-59 \times 37-42(59 \times 39)$ & ZMUC* & Krabbe $(1865)^{* *}$ \\
\hline
\end{tabular}

* uncatalogued; **type material 


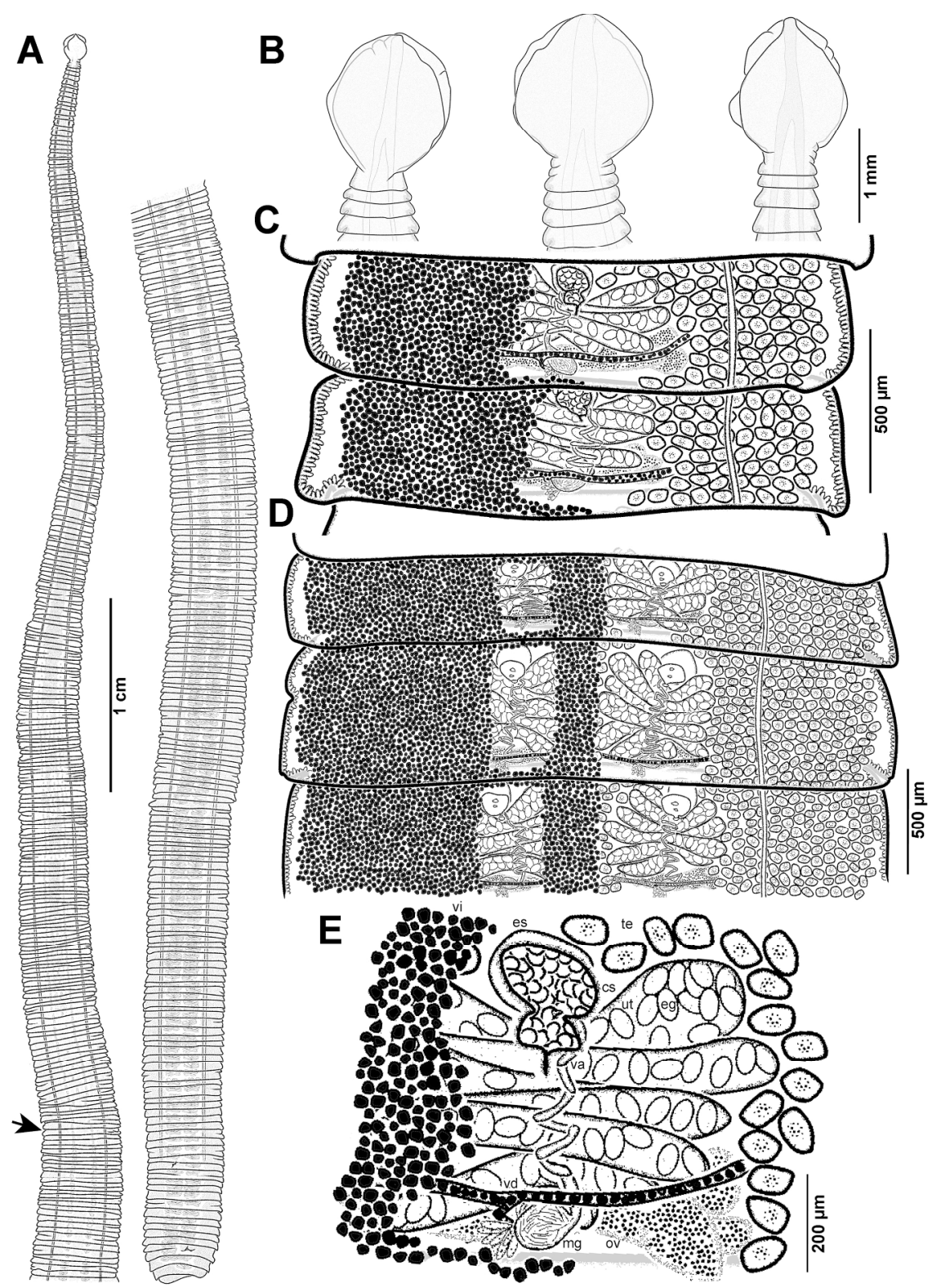

Fig. 1. Line drawings of Diphyllobothrium tetrapterum ex Callorhinus ursinus from St. Paul Island, Alaska. Whole contracted worm, ventral view, (A); Relaxed scoleces, lateral view (B); Mature relaxed monogonadic proglottids, ventral view (C); Mature relaxed diplogonadic proglottids, ventral view (D); Reproductive organs, ventral view (E). Note: vitelline follicles omitted on the right side of proglottids. Abbreviations: CS, cirrus-sac; eg, egg; es, external seminal vesicle; mg, Mehlis' gland; ov, ovary; te, testes; ut, uterus; va, vagina; vd, viteloduct; vi, vitelline follicles. 


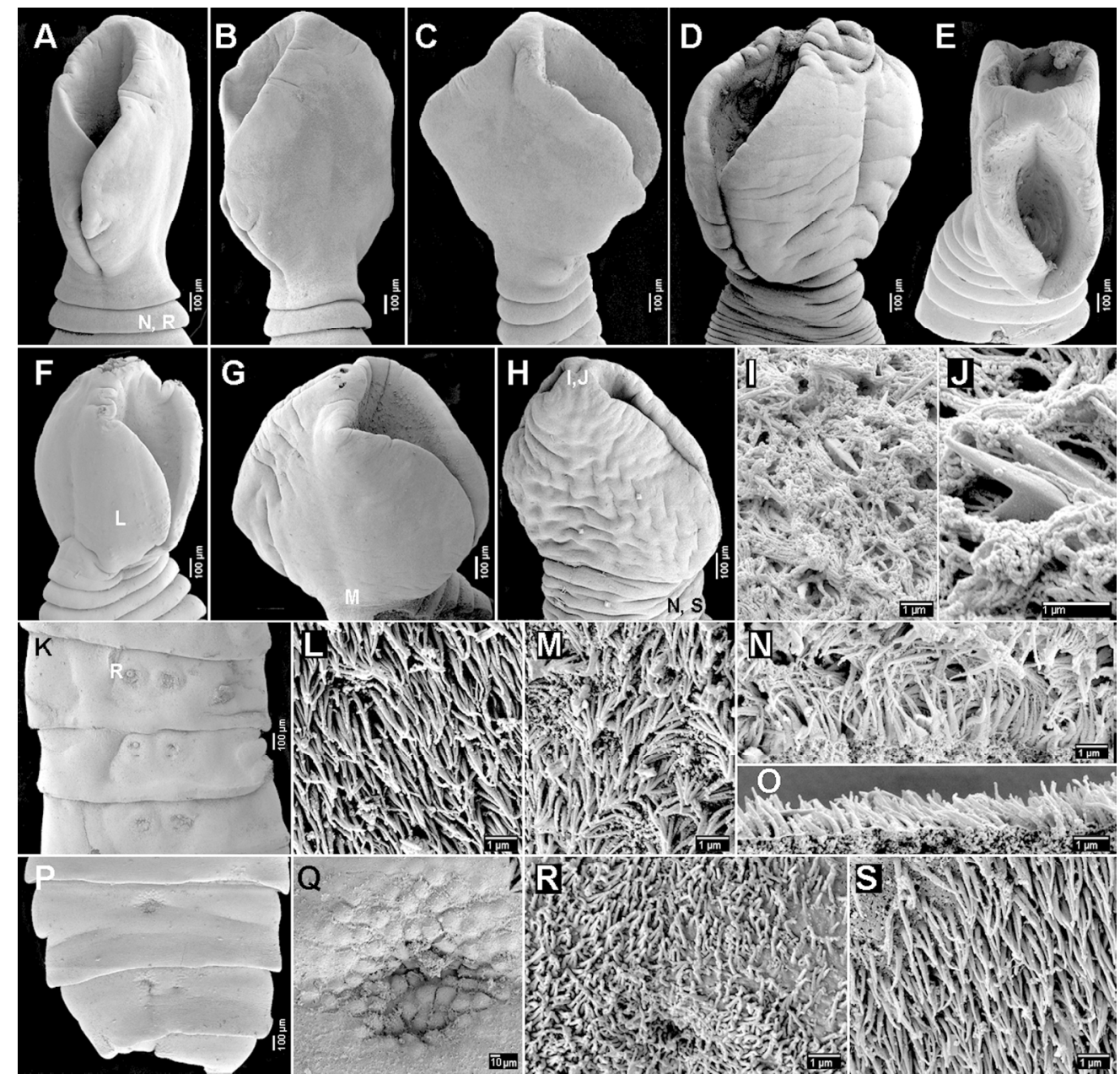

Fig. 2. Scanning electron micrographs of Diphyllobothrium tetrapterum ex Callorhinus ursinus from St. Paul Island, Alaska (A-G, K-M, O-R) and plerocercoid ex Onchorhynchus gorbuscha from Alaska (H-J, N, S). Scolex $(A-G)$; surface of scolex and strobila covered with uniform capilliform filitriches $(L, M, O)$; surface of the plercocercoid covered with capiliform filitriches, apical part of scolex also with interspersed, isolated uncinate spinitriches ( $\mathrm{J})$, posterior part of the scolex and rest of plerocercoid covered with numerous capilliform filitriches $(N, S)$. Gravid diplogonadic proglottids (K) with detail of the cirrus covered with acicular filitriches (Q). Posterior part of strobila with monogonadic proglottids $(P)$ with detail of the genital pore (Q). 


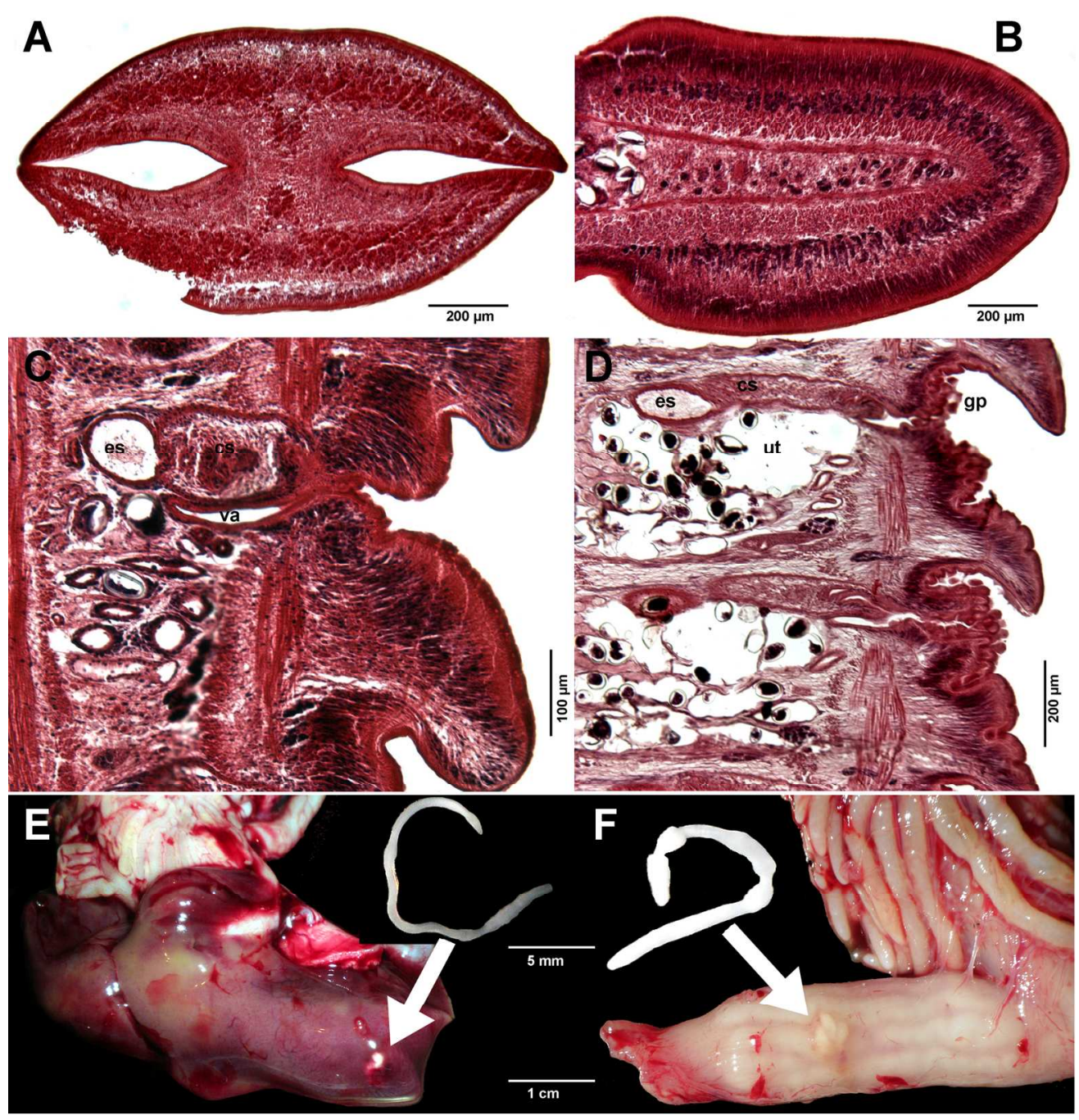

Fig. 3. Photomicrographs of histological sections of Diphyllobothrium tetrapterum ex Callorhinus ursinus from St. Paul Island, Alaska (A-D) and pleroceroids in situ of the liver (E) and stomach wall (F) Oncorhynchus gorbuscha with excysted specimens. Abbreviations: cs, cirrus-sac; es, external seminal vesicle; gp, genital pore; ut, uterus; va, vagina.

$$
165 \times 170 \mathrm{~mm}(300 \times 300 \text { DPI) }
$$



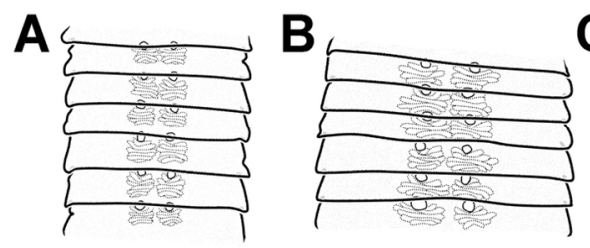

D
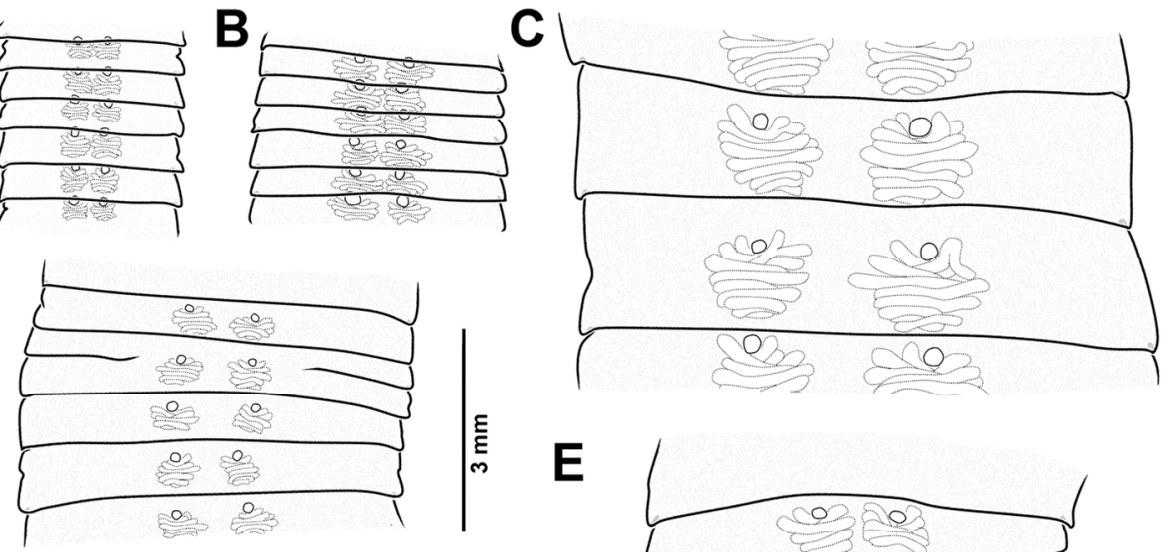

焉 E
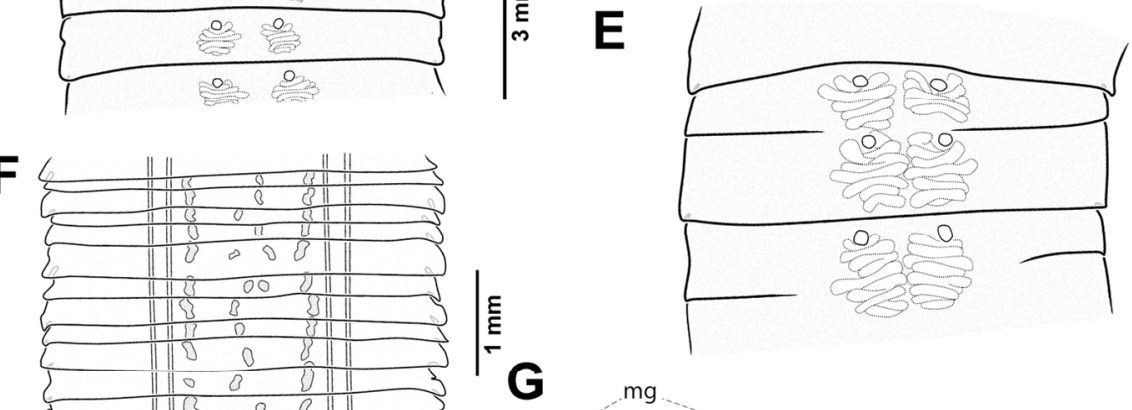

G
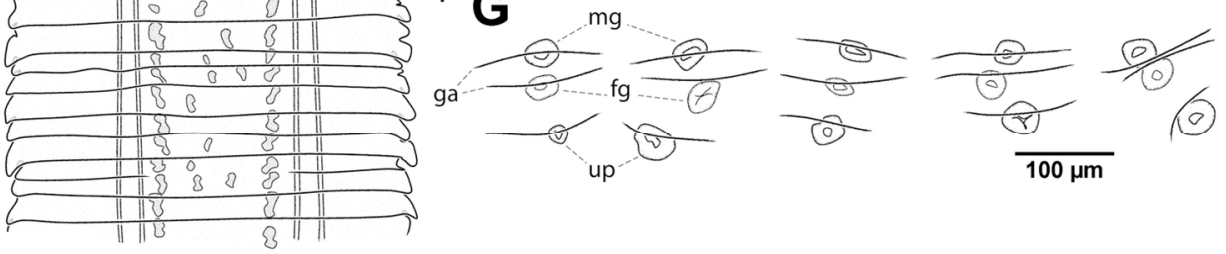

Fig. 4. Schematic drawings of proglottids of Diphyllobothrium tetrapterum from different marine mammals hosts. Gravid proglottids (A-E same magnification) ex Callorhinus ursinus from Alaska (A); ex Eumetopias jubatus from Alaska (HWHL 31751) (B) and from the Bering Sea, Arctic (C); ex Phoca vitulina from Greenland (ZMUC, uncatalogued - type material of Bothriocephalus variabilis) (D); ex E. jubatus from the Bering Sea, Russia (from type series of Diplogonoporus violettae) (E). Ventral view of immature diplo-, triplo- or tetraplogonadic segments (F) and positions of genital and uterine pores opening in gravid diplogonadic segments (G) ex C. ursinus from Alaska. Note: fg, female gonopore; ga, genial atrium; mg, male gonopore; up, uterine pore.

$133 \times 112 \mathrm{~mm}(300 \times 300$ DPI $)$ 
Diphyllobothrium tetrapterum specimen source:

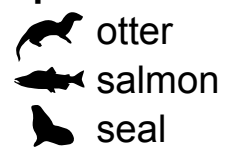

\section{Genital organs condition:}

$\triangle$ single set per segment $\triangle \triangle$ doubled

$D$ single \& rotated

$\triangleright \triangleleft$ doubled \& rotated

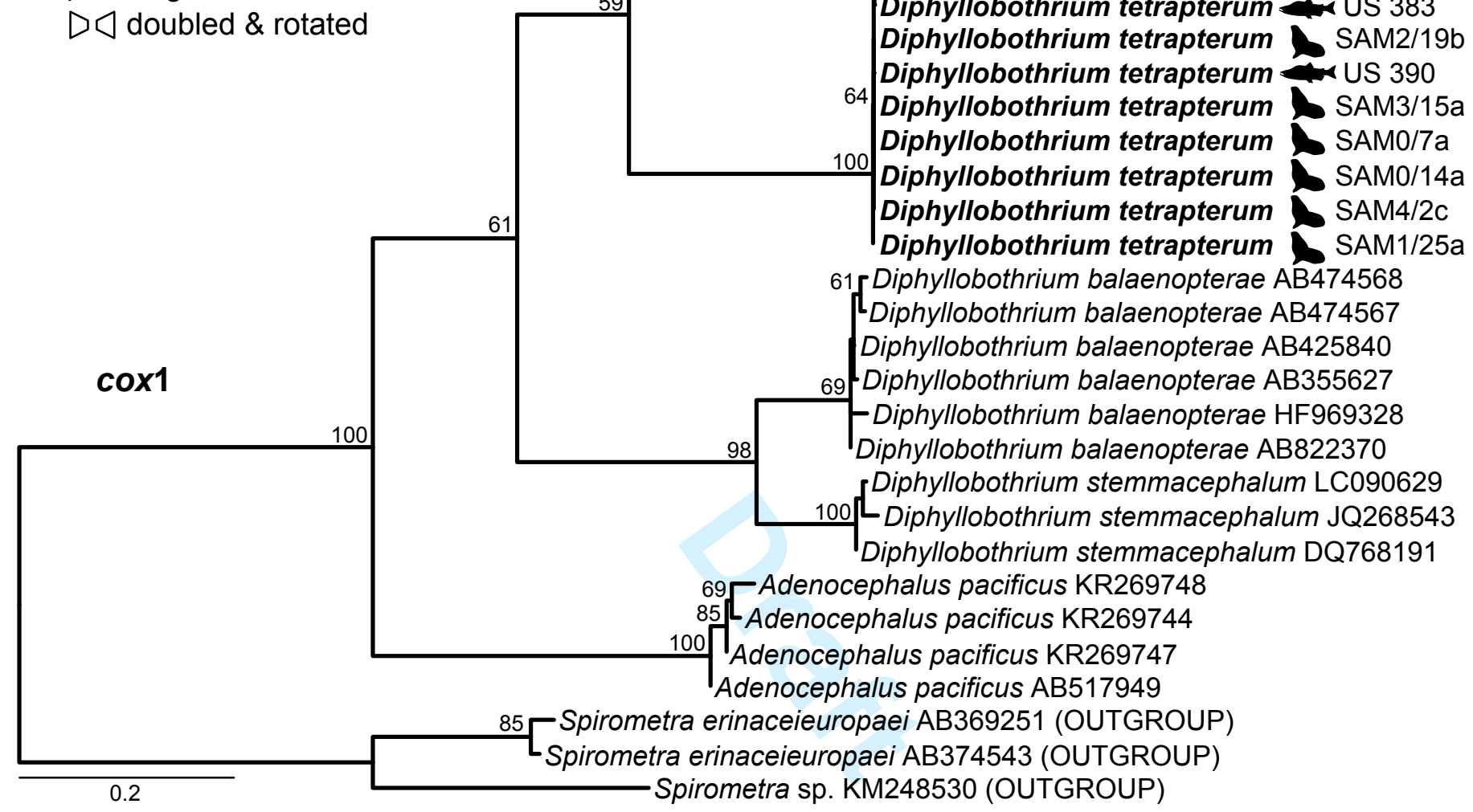

92. Dibothriocephalus dendriticus JN153004

100 Dibothriocephalus dendriticus JN153000

Dibothriocephalus ursi AB605763

57 Dibothriocephalus nihonkaiensis AM412560

Dibothriocephalus nihonkaiensis AB597274

98 Dibothriocephalus latus FM209180

Dibothriocephalus latus AB269325

Dibothriocephalus ditremus FM209182

Dibothriocephalus ditremus JQ245474

99 Ligula sp. EU241248

60|Diphyllobothrium tetrapterum KX227385

Diphyllobothrium tetrapterum SAM3/15a

$\triangle$

00

DAphyllobothrium tetrapterum $\mathrm{SAM} / 14 \mathrm{a}$

$\triangle \triangle$

SAM $4 / 2 \mathrm{c}$

$\triangle \triangle$

Diphyllobothrium balaenopterae AB474568

Diphyllobothrium balaenopterae AB474567

Diphyllobothrium balaenopterae AB425840

$\triangle \triangle$

Diphyllobothium stemmacephalum LC090629

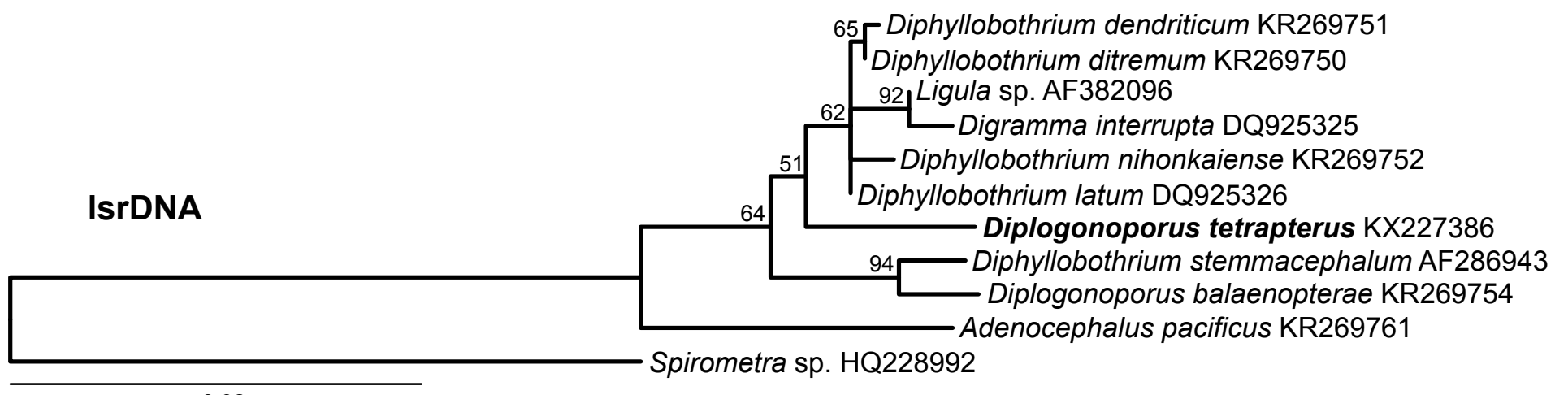




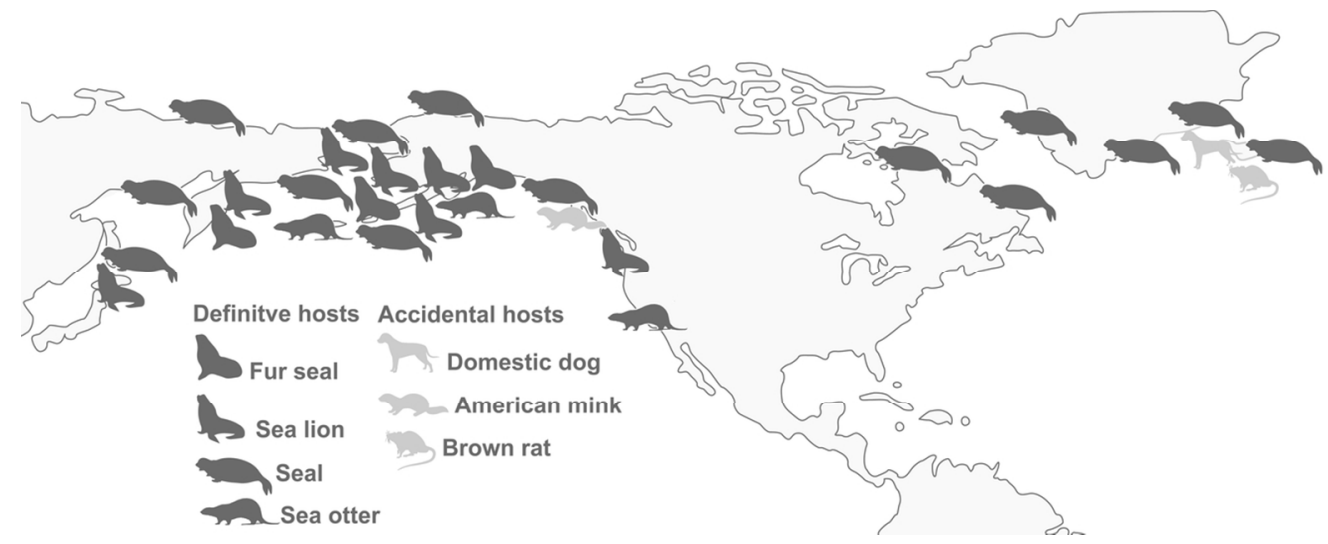

Fig. 6. Geographical distribution of Diphyllobothrium tetrapterum on the North Hemisphere.

$111 \times 44 \mathrm{~mm}(300 \times 300 \mathrm{DPI})$ 